\title{
"An order of deep-fried two-by-fours please!"
}

\author{
by P.A. Cooper ${ }^{1}$, J. Wang ${ }^{2}$ and Y.T. Ung ${ }^{3}$
}

\section{ABSTRACT}

Thermal modification of wood by immersion in high temperature vegetable oils and other additives impart significant decay and mould fungi resistance, water repellency and dimensional stability.

Key words: thermal modification, wood, vegetable oil, decay, termite resistance, oil stability

\section{RÉSUMÉ}

La modification thermique du bois par immersion dans de l'huile végétale et autres additifs à haute température modifie de façon significative le niveau de la décomposition du bois et de la résistance aux champignons de moisissure, l'imperméabilité à l'eau et la stabilité dimensionnelle.

Mots clés : modification thermique, bois, huile végétale, décomposition, résistance aux termites, stabilité glycérophtalique

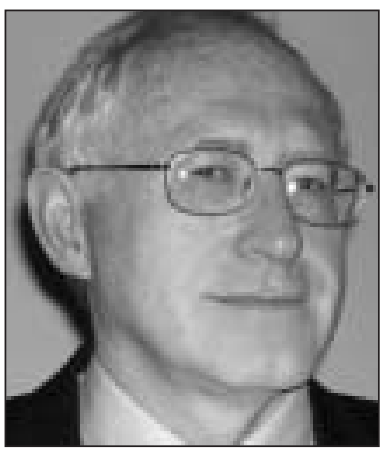

P.A. Cooper

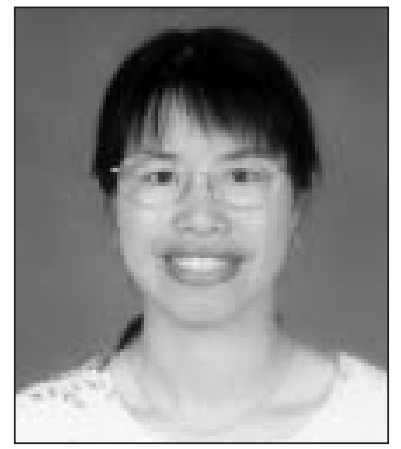

J. Wang

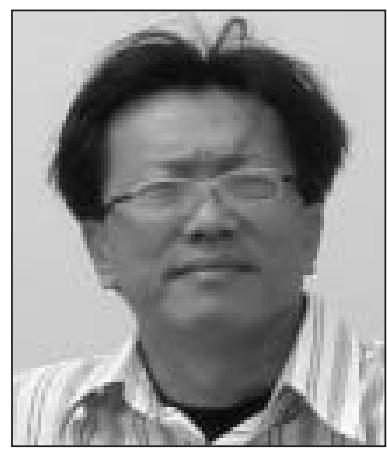

Y.T. Ung

\section{Introduction}

"Boiling in oil" sounds more like a medieval torture technique than a way to add value to wood products. However, thermal modification of wood in hot vegetable oil presents an interesting and environmentally friendly way to modify the properties of wood to be used in exterior above-ground applications such as fencing, cladding and other residential construction (Sailer et al.2000, Rapp and Sailer 2001). The potential of this process as a replacement for pressure-treated wood in some of these applications is being investigated by the Wood Science Group at the Faculty of Forestry, University of Toronto, supported by Natural Resources Canada ("Value-to-Wood" program) (Wang and Cooper 2003; 2004; 2005a, b).

Exposure of wood to high temperatures $\left(180-240^{\circ} \mathrm{C}\right)$ in the absence of oxygen changes the chemistry of the wood, darkens its colour, renders it more dimensionally stable and provides some resistance to decay (Stamm and Hansen 1937; Seborg et al. 1953; Burmester 1973; Bourgois et al. 1988; Boonstra et al. 1998; Tjeerdsma et al. 1998, 2000; Kamden et al. 2000, 2002; Kamden 2002; Bekhta and Niemz 2003). Achievement of these conditions has led to development of a number of technologies, ranging from treatment in molten metal to high temperature treatment under nitrogen or steam

in ovens or kilns (Stamm and Hansen 1937, Bourgois et al. 1988, Boonstra et al. 1998, Tjeerdsma et al. 2000). One interesting variation, developed in Germany, is to submerge wood in high-temperature vegetable oil in a process similar to the deep frying of foods such as French fries (Sailer et al. 2000, Rapp and Sailer 2001).

\section{Why Does Thermal Modification in Oil Make Sense? Decay resistance}

Many exterior, above-ground applications require only modest decay protection because the location and construction practices partially exclude moisture or allow drainage of water so that wood is only intermittently susceptible to decay. Examples of such applications are fence boards, decorative trim and siding.

Thermal modification in oil treatment ensures moderate durability for above-ground applications because:

- It modifies the hygroscopic hemicelluloses. This lowers the wood's affinity to water and reduces the wood moisture content at equilibrium with a given humidity condition. These changes interfere with the penetration of fungal enzymes and their reaction in the wood cell walls. For example, standard laboratory decay tests against brown rot

\footnotetext{
${ }^{1}$ Faculty of Forestry, University of Toronto, 33 Willcocks St., Toronto, Ontario M5S 3B3. E-mail: p.cooper@utoronto.ca ${ }^{2}$ FPInnovations, Forintek Division, 2665 East Mall, Vancouver, British Columbia V6T 1W5.

${ }^{3}$ Faculty of Forestry, University of Toronto, 33 Willcocks St., Toronto, Ontario M5S 3B3.
} 
and white rot fungi show greatly reduced weight losses, but not to the extent achieved by standard wood preservatives. Also, hot-oil-treated samples exposed to mould spores and high humidity in the laboratory had significantly higher resistance than untreated control samples (Wang and Cooper 2004, 2005a). Hence, the oils taken up by wood do not accelerate the mould growth on wood.

- It causes chemical changes to sugars and other wood components making the material less palatable to fungi.

- The oil- and water-repellent additives contribute water resistance, reducing the likelihood that the wood will reach a high enough moisture content to support decay (Wang and Cooper 2004).

\section{Environmental benefits}

The enhanced durability allows substitution of thermally modified material for preservative-treated wood in the above applications, reducing potential impacts because the process uses natural renewable materials, although processing energy requirements are higher than for preservative treatments.

\section{Through-and-through treatment}

Most Canadian species are only superficially treated with preservatives due to thin sapwood and non-permeable heartwood. Thermal treatment depends only on heat transfer, which is independent of permeability, thus wood is thermally modified to its full depth.

\section{Improved dimensional stability}

The thermal modification, by reducing the cell wall's affinity for moisture, results in lower swelling and shrinkage in response to humidity changes and exposure to water. This, in combination with the improved water repellency, results in less checking, splitting and warping in service. The performance can be enhanced by coating the samples with an acrylic (water-based) stain. The combined effect of lower affinity for moisture and increased water repellency from the oil results in a reduction in dimensional change of about 50\% (antishrink efficiency). Samples exposed vertically out-of-doors over one year fluctuated less than $5 \%$ in moisture content compared to more than $20 \%$ for untreated or preservative treated wood (Wang and Cooper 2004).

\section{Appearance}

Treated wood is a pleasing brown colour, which can mask colour imperfections such as blue stain.

\section{Are There Limitations and Disadvantages?}

Despite the many potential benefits of thermal modification, it has some adverse effects on wood properties and performance:

- Treated wood is not resistant to termites or other wooddegrading insects. Choice and no-choice laboratory tests showed that termites successfully degraded thermally modified wood and even preferred it over untreated wood.

- The wood is weakened by the treatment. Bending stiffness is not reduced significantly, but bending strength is reduced by about $20 \%$ and abrasion resistance and toughness may be reduced by $40 \%$ to $50 \%$ with treatment at $220^{\circ} \mathrm{C}$ for two hours. These strength losses are still acceptable for most anticipated applications, such as decking, cladding and fencing.
- The coloured wood is not resistant to UV degradation, so it should be stained or otherwise protected for exterior uses.

- The oil used during the treatment process eventually degrades and options for reuse, recycling or disposal must be considered.

\section{How About Some Rosemary or Sage with Your Deep-Fried Wood?}

One of the goals of our investigations is to maximize the useful life of the oils. Like deep-frying oil in a restaurant setting, the oil eventually degrades resulting in unpleasant smell and taste and, more importantly for wood treatment, thickening and even solidification of the oil. The high temperatures used in the thermal process accelerate this degradation so that oils are very viscous and solidify at room temperature after about one week of continuous wood treatment.

We looked at a number of approaches to extending the oil life, including additives such as "slack wax," surface films such as silicone oil to exclude oxygen (apparently a common practice with French-fry oil) and use of known anti-oxidants including the dry herbs, sage and rosemary. All additives effectively increased the working life of the oil. For example, $50 \%$ slack wax more than doubled the effective life of the oil, while the dry herbs at only $0.75 \%$ of the oil weight were nearly as effective as the slack wax.

Additional benefits of slack wax (a low-cost mixture of petroleum oils and waxes used as a water repellent in the composites industry) are that it is less costly than vegetable oils so it reduces the over-all oil cost and it enhances the water repellency of the treatment.

\section{Next Steps}

While much of the focus of our research group is on extending the life of products through wood preservatives, we see thermal modification with renewable vegetable oils as a viable alternative to pesticides for some applications and we will continue to develop the process as part of our research program.

\section{References}

Bekhta, P. and P. Niemz. 2003. Effect of high temperature on change in color, dimensional stability and mechanical properties of spruce wood. Holzforschung 57: 539-546.

Boonstra, M.J., B.F. Tjeerdsma and H.A.C. Groeneveld. 1998. Thermal modification of non-durable wood species. 1. The Plato technology: Thermal modification of wood. IRG/WP 98-40123, IRG Secretariat, Stockholm, Sweden.

Bourgois, J., R. Guyonnet and S. Etienne. 1988. Characterization and analysis of torrefied wood. Wood Sci. Technol. 22: 143-155.

Burmester, A. 1973. Effect of heat-pressure-treatment of semi-dry wood on its dimensional stability. Holz als Roh- und Werkstoff 31: 237-243.

Kamdem, D.P. 2002. Heat treatment: Can it replace preservatives? CWPA (Canadian Wood Preservation Association) Proceedings. pp. 122-131.

Kamdem, D.P., A. Pizzi and M.C. Triboulot. 2000. Heat treated timber: potentially toxic byproducts presence and extent of wood cell wall degradation. Holz als Roh- und Werkstoff 58: 253-257.

Kamdem, D.P., A. Pizzi and A. Jermannaud. 2002. Durability of heat-treated wood. Holz als Roh- und Werkstoff 60: 1-6.

Rapp, A.O. and M. Sailer. 2001. Oil heat treatment of wood in Germany-State of the art. In A.O Rapp (ed.). Review on heat treatments of wood. Proceedings of the special seminar held 9 February 
2001 in Antibes, France. pp. 43-60. Forestry and Forestry Products, France. COST Action E22, EUR 19885.

Sailer, M., A.O. Rapp, H. Leithoff and R.-D. Peek. 2000. Upgrading of wood by application of an oil-heat treatment. Holz als Roh- und Werkstoff 58: 15-22.

Seborg, R.M., H. Tarkow and A.J. Stamm. 1953. Effect of heat upon the dimensional stabilization of wood. J. For. Prod. Res. Soc. 3: 59-67. Stamm, A.J. and L.A. Hansen. 1937. Minimizing wood shrinkage and swelling: Effect of heating in various gases. Ind. Eng. Chem. 29(7): 831-833.

Tjeerdsma, B.F., M. Boonstra, and H. Militz. 1998. Thermal modification of non-durable wood species: 2. Improved wood properties of thermally treated wood. The international research group on wood preservation, IRG/WP 98-40124, IRG Secretariat, Stockholm, Sweden.

Tjeerdsma, B.F., M. Stevens and H. Militz. 2000. Durability aspects of (hydro)thermal treated wood. The international research group on wood preservation, IRG/WP 00-40160, IRG Secretariat, Stockholm, Sweden.

Wang, J. and P.A. Cooper. 2003. Thermal oil heat treatments to protect and stabilize wood. In Proceedings Can. Wood Preserv. Assoc. $24^{\text {th }}$ Annual Conference, Halifax. NS. Oct. 27-28, 2003.

Wang, J. and P.A. Cooper. 2004. Moisture properties and biological resistance of hot oil treated wood. In Can. Wood Preserv. Assoc. $25^{\text {th }}$ Annual Conference, Vancouver, B.C. Oct. 26-27, 2004.

Wang, J. and P.A. Cooper. 2005a. Effect of oil type, temperature and time on moisture properties of hot oil-treated wood. Holz als Rohund Werkstoff. 63: 417-422.

Wang, J. and P.A. Cooper. 2005b. Properties of hot oil treated wood and the possible chemical reactions between wood and soybean oil during heat treatment. Int. Res. Group on Wood Preserv. Doc. IRG/WP 05-40304. IRG Secretariat, Stockholm, Sweden. 